\title{
The Paracentrotus lividus populations from the northern Moroccan Atlantic coast: growth, reproduction and health condition
}

\author{
Abdellatif Bayed*, Françoise Quiniou ${ }^{\dagger}$, Ali Benrha ${ }^{\ddagger}$ and Monique Guillou ${ }^{\S \S}$ \\ *Institut Scientifique, Avenue Ibn Battota, BP 703, 10106 Rabat, Morocco. ${ }^{\dagger}$ Département Biogéochimie et Ecotoxicologie, \\ IFREMER, Gentre de Brest, BP 70, 29280 Plouzané, France. ${ }^{\ddagger}$ Laboratoire d’Ecotoxicologie, Institut National de Recherche \\ Halieutique, Casablanca, Morocco. ${ }^{\int}$ LEMAR, UMR CNRS 6539, Institut Universitaire Européen de la Mer, \\ UBO, 29280 Plouzané, France. ${ }^{\S}$ Corresponding author, e-mail: mguillou@univ-brest.fr
}

The condition of three intertidal Paracentrotus lividus populations, which inhabit an area between Rabat and Casablanca (Morocco) known by its high wave energy and its substantial anthropogenic disturbances were described. The growth rate of the juvenile sea urchins in this intertidal zone was low compared with more sheltered populations. A sharp increase in the gonad index was observed between January and March at the beginning of a period of algal production, and was concomitant with increases in seawater temperature and food consumption rate. This gonad index increase was followed by a single spawning period occurring between March and June, probably triggered by the phytoplankton bloom induced by upwelling conditions. Larval development in all three populations was severely inhibited and could be explained, in part, by high and generalized $\mathrm{Cu}$ contamination throughout the region. Specific contamination of particular populations by $\mathrm{Pb}$ or $\mathrm{Hg}$ was attributed to local industries and the incomplete dispersion of pollutants in spite of the high hydrodynamics along the Moroccan Atlantic coast. One of the three populations studied showed strong indications of abnormal development; the degradation of its condition appeared to be due to the presence of a wadi (temporary river) which can seasonally reduce the salinity, directly affecting the sea urchin physiology and indirectly enhancing the metal toxicity.

\section{INTRODUCTION}

The Atlantic-Mediterranean sea urchin Paracentrotus lividus (Lamarck) (Echinodermata: Echinoidea) is an opportunistic species having an important ecological role in different ecosystems. Paracentrotus lividus is distributed from Ireland to southern Morocco, including throughout the Mediterranean Sea. This sea urchin inhabits a broad range of substrates from rocks and boulders, to sea grass meadows or maerl beds, and lives from the low-water limit down to about $20 \mathrm{~m}$ depth. Paracentrotus lividus shows a wide range of adaptive responses to environmental conditions such as temperature, food, and wave action (see review by Boudouresque \& Verlaque, 2001). Human activities in coastal zones can also alter $P$. lividus physiology, biology and demography, and over the longterm can modify its ecological role (Dinnel et al., 1988). The sedentary habit of $P$. lividus and its sensitivity to pollutants has led to their use as biological-biochemical indicators of local pollution (Dinnel et al., 1987, 1988).

On the Moroccan Atlantic coast, populations of $P$. lividus occur mainly in intertidal pools on rocks in very exposed conditions. They are exposed both to strong hydrodynamic forces in this intertidal zone and to anthropogenic disturbance from coastal discharges of untreated industrial and agricultural effluents. This study has focused on $P$. lividus populations found between Rabat and Casablanca. More than $40 \%$ of the urban Moroccan population, or more than 5.5 million persons, live along this coastline (Chafik et al., 2001). The purpose of this paper is to describe the condition of $P$. lividus populations occurring along this coastline by analysing their growth, reproductive cycle and ability to produce viable larvae, and to compare these parameters with those of other P. lividus populations in different ecological situations.

\section{MATERIALS AND METHODS}

Study area

The coast between Rabat and Casablanca (Figure 1) is generally rocky with short beaches in places. At the seawater surface, the currents parallel the coast. This roughly straight coast is beaten by a swell, generally from the north-west, that contributes to create a strong hydrodynamic environment in the sea urchin habitats. The tides are semidiurnal in the study areas with an amplitude varying between 2.5 and $3 \mathrm{~m}$ during spring tides and between 1.3 to $1.4 \mathrm{~m}$ during neap tides. Between Rabat and Casablanca, the seawater temperature has an annual cycle with the maximum occurring during July-August and the minimum between December and February, and varies, on average, between 14 and $26^{\circ} \mathrm{C}$. In the vicinity of the study sites the seawater salinity varied seasonally between 30 and 34, and was altered by rainfall, by the presence of waterways or wastewater discharge to the 


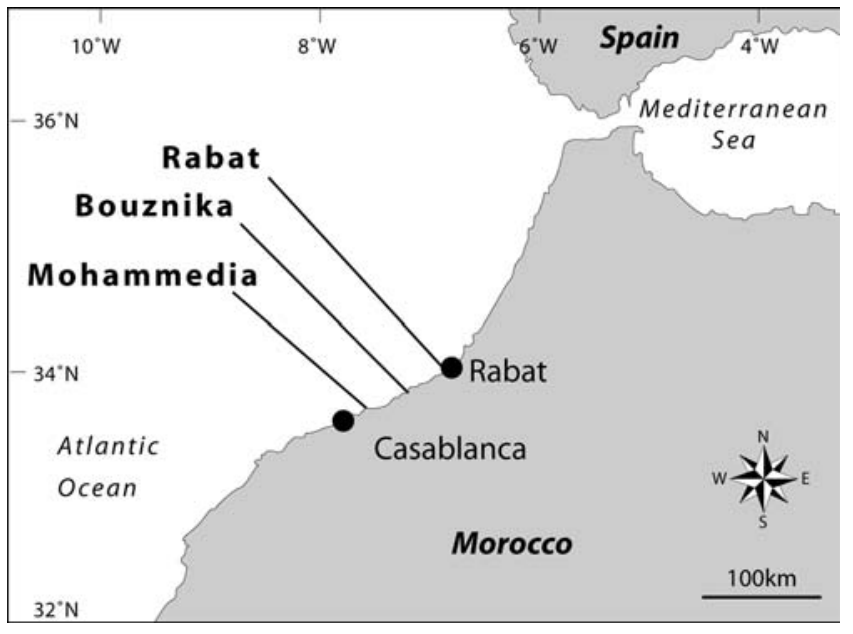

Figure 1. Location of the stations along the Moroccan Atlantic coast between Rabat and Casablanca: Rabat, Bouznika and Mohammedia.

ocean and can decrease locally below 20 (Bayed, 1991; Chafik et al., 2001).

Three sites were selected based on their proximity to different levels of disturbances (Figure 1). In Rabat, the studied population of Paracentrotus lividus occupied submerged crevices on a rock ledge that emerged at semitide. The sampling station $\left(34^{\circ} 01.86^{\prime} \mathrm{N} 06^{\circ} 50.65^{\prime} \mathrm{W}\right)$ was located at a few tens of metres from a mouth of urban waste at Rabat and just a few hundred metres from the mouth of the Oued Bou Regreg that drains a part of the wastewater of the towns of Rabat and Salé. The handmade pottery industry of Sale is the origin of water pollution from lead oxide used in glazes (Cheggour, 1989).

The site at Bouznika is about halfway between Rabat and Mohammedia. The sampling station $\left(33^{\circ} 48.35^{\prime} \mathrm{N}\right.$ $07^{\circ} 09.78^{\prime} \mathrm{W}$ ) was located south-west of Bouznika on a rock ledge. The bathymetric level is lower than those of Rabat and Mohammedia. A wadi (temporary river) flows into the sea along this rock ledge and drains also untreated wastewater from the dwellings located along its way. During low tide, this water flow can cause significant decreases in salinity that may result in locally mixohaline water (less than 20, M.G., personal observation). This site is theoretically far from any sources of industrial pollution.

At Mohammedia, the sampling station $\left(33^{\circ} 40.87^{\prime} \mathrm{N}\right.$ $07^{\circ} 26.23^{\prime} \mathrm{W}$ ) was located south-west of the city. The $P$. lividus population occupied crevices in a rock ledge which was at a bathymetric level comparable to Rabat. Mohammedia is the centre of the Moroccan petroleum industry. It is a highly industrialized site with about 200 active factories (petrochemical and parachemical, mechanical and electric engineering industries).

\section{Sampling}

Sea urchins were sampled from each site at monthly intervals from April 1999 to April 2000, in crevices on the rock ledges using a wooden spatula. For growth estimation, a crevice where all the size-classes were present was chosen. All the sea urchins present in three quadrats of $25 \times 25 \mathrm{~cm}$ were sampled to obtain a minimum of 50 individuals. Concomitantly about 50 sea urchins of
30-35 mm diameter were sampled for estimation of the righting time and physiological indices. When fertilization and metal contamination analysis were carried out, further individuals of the same size were sampled to select 10 males and 10 females for each analysis. All the individuals were maintained in tanks with seawater from the site in the laboratory.

\section{Growth}

The diameter of each individual specimen was measured with Vernier callipers with the points inserted between the spines. Growth was estimated by diameterfrequency distributions. The specimens were grouped into size-classes of $4 \mathrm{~mm}$. The set of normal components was adjusted to each monthly size-frequency distribution using the MIX3 software package (Macdonald \& Pitcher, 1979) which is based on the maximum likelihood determination. The growth of each component was estimated using the temporal change of the mean size.

\section{Physiological indices}

Two physiological indices were measured: the gonad index $(\mathrm{GI})$ to assess both the reproductive intensity and the spawning period, and the repletion index (RI) which indicates the intensity of food consumption. These indices are defined as follows: GI=gonad dry weight (in g) $/ \mathrm{D}^{3} \times 10^{6}$ and $\mathrm{RI}=$ gut content dry weight (in g) $/ \mathrm{D}^{3} \times 10^{6}$ where $\mathrm{D}$ is the sea urchin horizontal diameter (in mm) (Nédélec et al., 1983). To minimize the bias due to the variation of the organ weight with respect to body size, a standard size-class was defined. Gonads, testes and gut contents were oven-dried separately at $60^{\circ} \mathrm{C}$ for $24 \mathrm{~h}$ before being weighed.

\section{Righting response}

The righting response is used in echinoderms as an indication of the physiological status of a specimen with respect to environmental changes and has been used as a measure of stress and organism well-being (Lawrence \& Cowell, 1996). Individuals were then inverted onto their dorsal surface and righting time (in seconds) was estimated when the oral surface of the disc and the ambulacra were again flat on the tank floor.

\section{Embryo development}

Experiments on fertilization and embryo-larval development were performed on sea urchins collected during the estimated spawning period, in March and May 2000. Experiments were started less than $6 \mathrm{~h}$ after collecting the sea urchins and using the seawater from the respective sites. Methods and procedures used to detect abnormalities in embryonic development and analyse results were the same as described in Guillou et al. (2000). Gametes were collected from 10 male and 10 female sea urchins. Two series of tests were carried out simultaneously: each male was tested using diluted oocytes from a pool of females and each female was tested using a pool of males, i.e. 20 tests were performed per site. The fertilization rate was evaluated by counting the percentage of fertilized eggs $1 \mathrm{~h}$ after 
MOHAMMEDIA
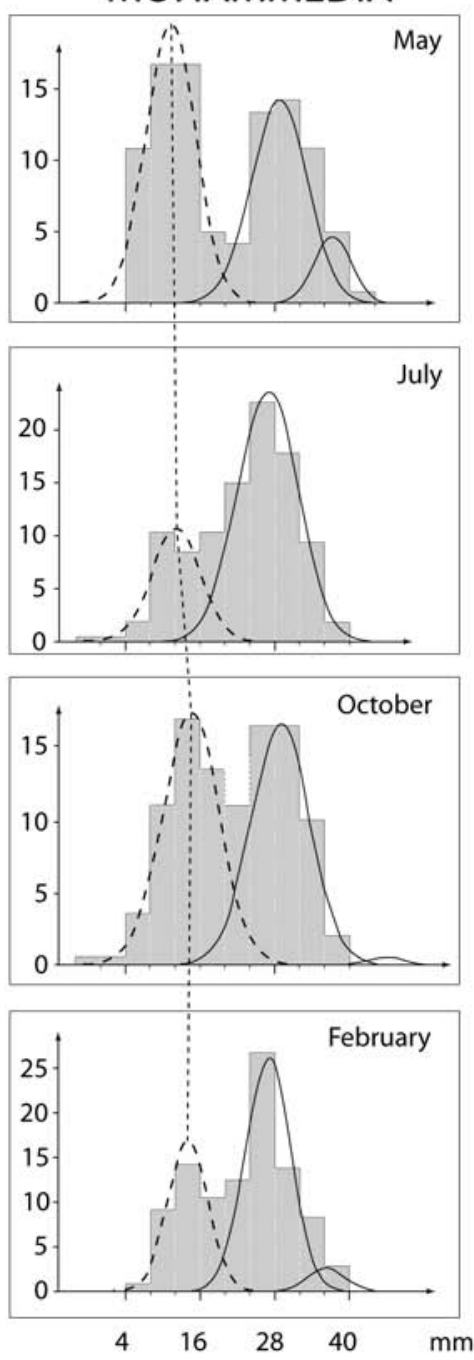

BOUZNIKA
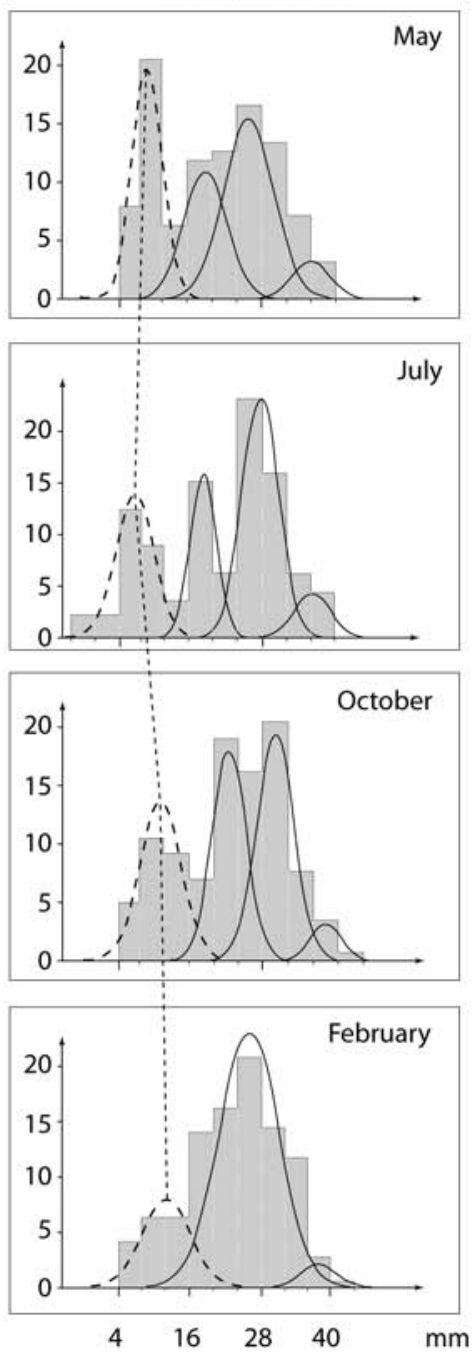

RABAT
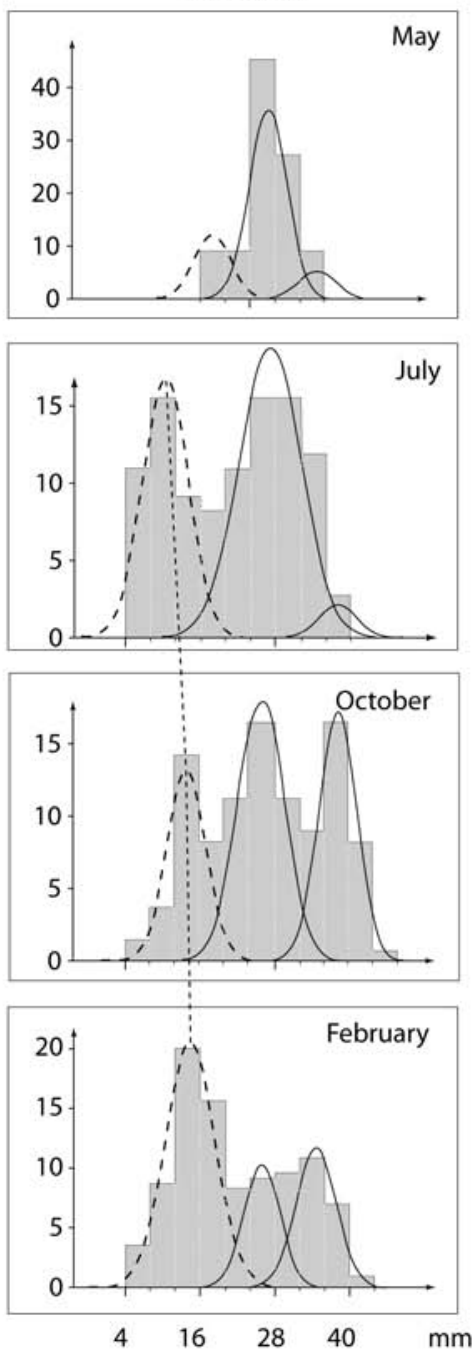

Figure 2. Diameter-frequency (\%) distributions of the Paracentrotus lividus collected from May 1999 to February 2000 in the three studied stations. Gaussian modes were isolated using the MIX3 software.

mixing the gametes. The embryonic development was evaluated over a $96 \mathrm{~h}$ incubation in a temperaturecontrolled room $\left(20 \pm 2{ }^{\circ} \mathrm{C}\right)$. For each sample, the results were determined for 100 pluteus larvae after fixation with buffered $8 \%$ formaldehyde $\left(16.5 \mathrm{ml} \mathrm{l}^{-1}\right)$. The following five criteria, defined by Pagano et al. (1989), were used in this study: (i) $\mathrm{N}=$ normal plutei; (ii) $\mathrm{R}=$ retarded or inhibited plutei exhibiting a size $<50 \%$ of the normal size $\mathrm{N}$; (iii) $\mathrm{Pl}=$ pathological plutei with skeletal malformations and/ or gut abnormalities; (iv) $\mathrm{E}=$ embryos whose development ended at blastula or gastrula stages; and (v) $\mathrm{D}=$ dead organisms represented by clusters of spicules. The results were expressed as the mean of both test series.

\section{Metal contamination}

Metal contents $(\mathrm{Cd}, \mathrm{Pb}, \mathrm{Cu}, \mathrm{Hg})$ in the gut walls and gonads of urchins were measured in the Laboratory of Chemical Pollutants at the Institut National de Recherche Halieutique (INRH) located in Casablanca (Morocco). The study was carried out in March 2000 along with the evaluation and analysis of embryo development. For each site, a set of urchins composed of 10 males and 10 females was analysed (60 samples in all). The gonads were removed, the guts were emptied of their contents and then they were rinsed with the site seawater. The samples were freeze-dried for $48 \mathrm{~h}$ (TELSTAR LIOALFA-6) and weighed to the nearest $0.1 \mathrm{mg}$. Gonads and gut walls were pooled by site and by sex reducing the number of samples to two by site. The pooled samples were weighed, then $0.2 \mathrm{~g}$ subsamples were digested in Teflon beakers with $4 \mathrm{ml}$ of $\mathrm{HNO}_{3}$ (for $\mathrm{Cd}, \mathrm{Pb}$ and $\mathrm{Cu}$ ) and $45 \mathrm{mg}$ of $\mathrm{V}_{2} \mathrm{O}_{5}$ and $5 \mathrm{ml}$ of $\mathrm{HNO}_{3}$ for the $\mathrm{Hg}$ analysis. Sample digestion using the IAEA-MESL method included an initial dissolution step for about $1 \mathrm{~h}$ at laboratory ambient temperature, which was followed by heating in a microwave oven for $2 \mathrm{~min} 20 \mathrm{~s}$ at $80^{\circ} \mathrm{C}$ then $5 \mathrm{~min}$ at $100^{\circ} \mathrm{C}$ to complete the sample digestion. The $\mathrm{Hg}$ analysis required oxidation of the prepared aliquot with the addition of $1 \mathrm{ml}$ of $\mathrm{K}_{2} \mathrm{Cr}_{2} \mathrm{O}_{7}$. The digested samples were diluted to $50 \mathrm{ml}$ with Milli-Q water. Mussel tissue corresponding to the standard reference material MIST, 1976 (Donais et al., 1997) was processed and analysed as a control sample, using the same protocol described above. The purity of the chemicals used was checked by analysis of appropriate blanks. All metal concentrations were measured using an 

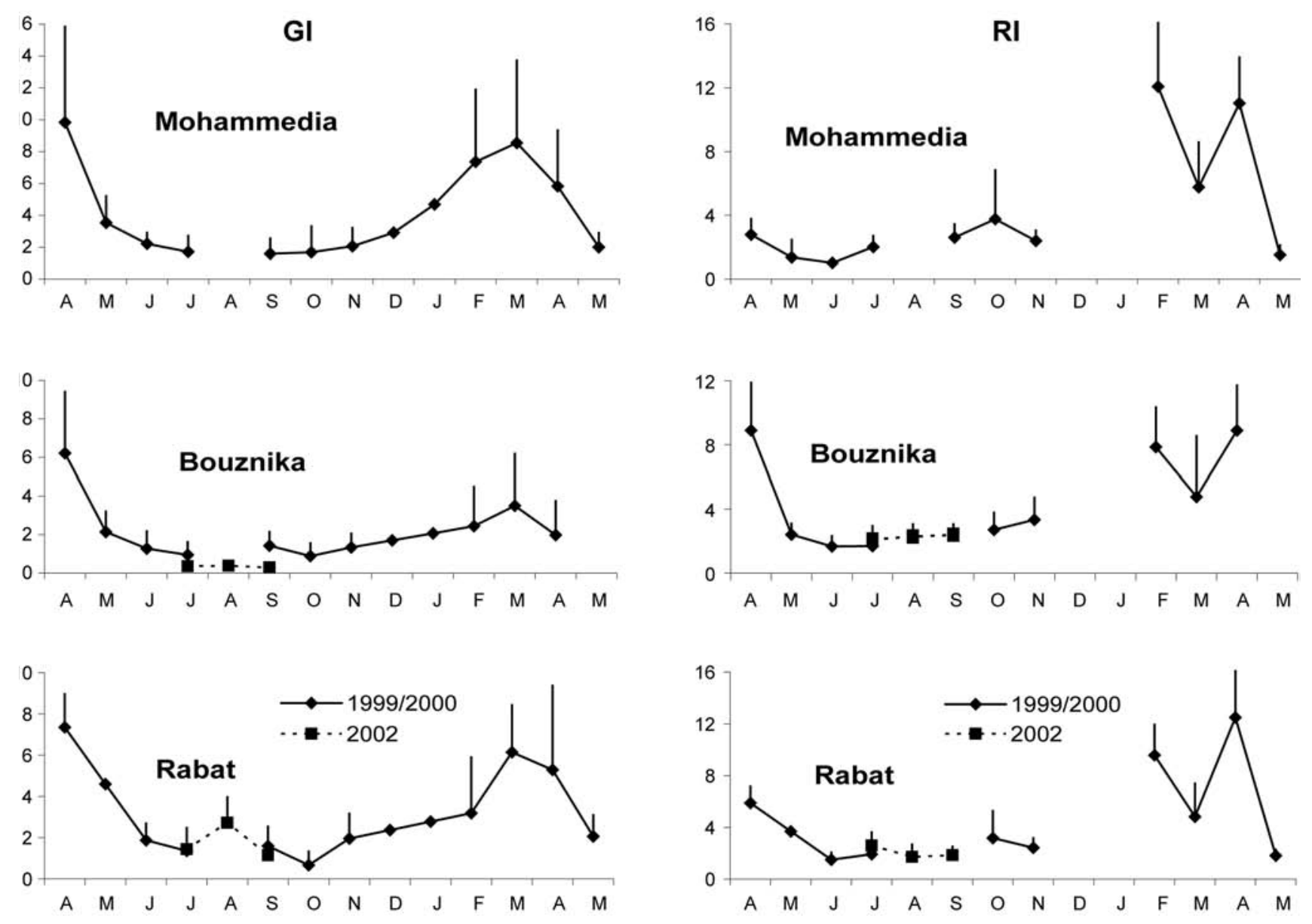

Figure 3. Seasonal changes in the gonad and repletion indices $( \pm \mathrm{SE})$ of the three Paracentrotus lividus populations determined during April 1999 through May 2000.

atomic emission spectrophotometer (Perkin-Elmer). Detection limits were $0.003,0.023,0.010$ and $0.024 \mu \mathrm{g} \mathrm{g}^{-1}$ (dry weight) for $\mathrm{Cd}, \mathrm{Pb}, \mathrm{Cu}$, and $\mathrm{Hg}$ respectively.

\section{Statistical analyses}

One-factor analysis of variance (ANOVA) $(P<0.05)$ was applied to compare the data: mean sizes of the first year-classes after the homogeneity of the variances had been tested. A 2-way ANOVA with time and locality as factors and subsequent Tukey HSD multiple mean comparison test were used to compare righting time and the physiological indices. For the embryo development, the $\mathrm{G}$ procedure was used to test the differences in the distributions observed for each larval class among the different populations (Pagano et al., 1996). At first the homogeneity of the three populations was tested then, if the hypothesis of heterogeneity was significant, the $\mathrm{G}$ test was applied to the sites in pairs to determine the populations responsible for this heterogeneity.

\section{RESULTS}

\section{Growth}

The size-frequency histograms of the three populations studied were divided into their Gaussian components. Four of these histograms are shown in Figure 2 for each site and each season. At three sites, two distinct groups of individuals can be observed: small size-group with a unique mode (individuals $<20 \mathrm{~mm}$ diameter) considered as the juvenile cohort and a larger sizegroup that can be polymodal according to the population. The juvenile cohort was not completely recruited before July; it formed a distinct separate mode until the following winter when it gradually merged with the group of older adult individuals. In this adult group, increasing growth variations with time did not allow an annual value for the Gaussian components to be attributed, and the age and growth cannot be estimated for the adults. Thus, growth variations between the studied populations were assessed using changes in the mean size of the first cohort during its first year of settlement in the site. In July, when the first cohort was considered completely recruited for all three sites, its mean size at Bouznika $(7.2 \mathrm{~mm})$ was significantly smaller than the mean size of individuals at Rabat and Mohammedia (10.4 and $12.4 \mathrm{~mm}$, respectively) $(P<0.05)$. In February, before the insertion of this juvenile cohort into the adult components, this first cohort was always the smallest at Bouznika with a mean size of $12.0 \mathrm{~mm}$, versus 14.5 and $14.0 \mathrm{~mm}$ in Rabat and Mohammedia, respectively. Individuals from Rabat had the highest growth rate during this same period. 


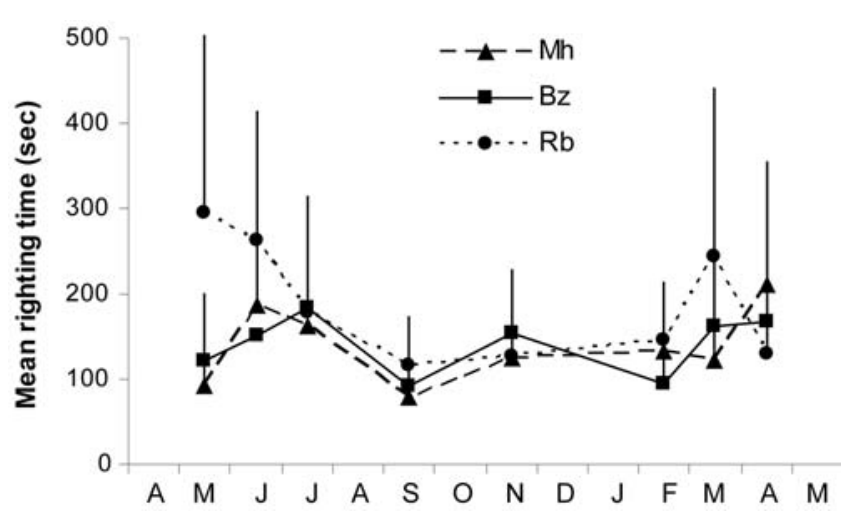

Figure 4. Seasonal changes in mean of righting time $( \pm \mathrm{SE})$ in seconds for the three Paracentrotus lividus populations.

\section{Reproductive cycle}

Changes in gonad indexes (GIs) pointed out only one annual decrease at the same period for the three sites studied. This drop can thus reflect the spawning event. This annual breeding season extended from March to June (Figure 3). The trend for the missing data between July and September 2000 was estimated with another sampling during 2002 at both Bouznika and Rabat; these complementary samples did not show significant changes during this period. The GIs were statistically different among time and localities (2-factor ANOVA for time, sites and interactions, $\mathrm{N}=650, P<0.001)$. The GIs were significantly higher in Mohammedia and lower in Bouznika than in the other sites. These differences occurred during the pre- and post-spawning periods (April and May 1999, $P<0.1$ then February, $P<0.001$ and March $2000 P<0.05)$.

Although data for December 1999 and January 2000 were missing, the changes in repletion indexes (RIs) were comparable between the sites (Figure 3). The RIs were statistically different among time and localities (2-factor ANOVA for time, sites and interactions, $\mathrm{N}=627$, $P<0.01)$. Over the sampling period, RIs were significantly higher in Rabat and lower in Mohammedia. This was due to the lack of peak in April 1999 in Mohammedia. In 2000 peaks in indexes were observed just before spawning (February 2000) and during the spawning period (April 1999 and April 2000). The two highest index values were observed at Mohammedia, in February, one month before spawning $(P<0.005)$ and at Rabat, in April, during spawning $(P<0.01)$. The RI decreased significantly between February and March 2000 when the GI was at its maximum. In spring and summer, the RI was low and there were no significant differences between the three stations.

\section{The righting response}

Variations in righting time were statistically different among time and localities (2-factor ANOVA for time, sites and interactions, $\left.\mathrm{N}=926, P<10^{-5}\right)$. Righting time was significantly higher in Rabat than in the two other sites (Figure 4). At the three sites, the righting times decreased significantly between July and September (Tukey HSD test for time $P=10^{-4}$ ) and increased between February and March (Bouznika and Rabat) or
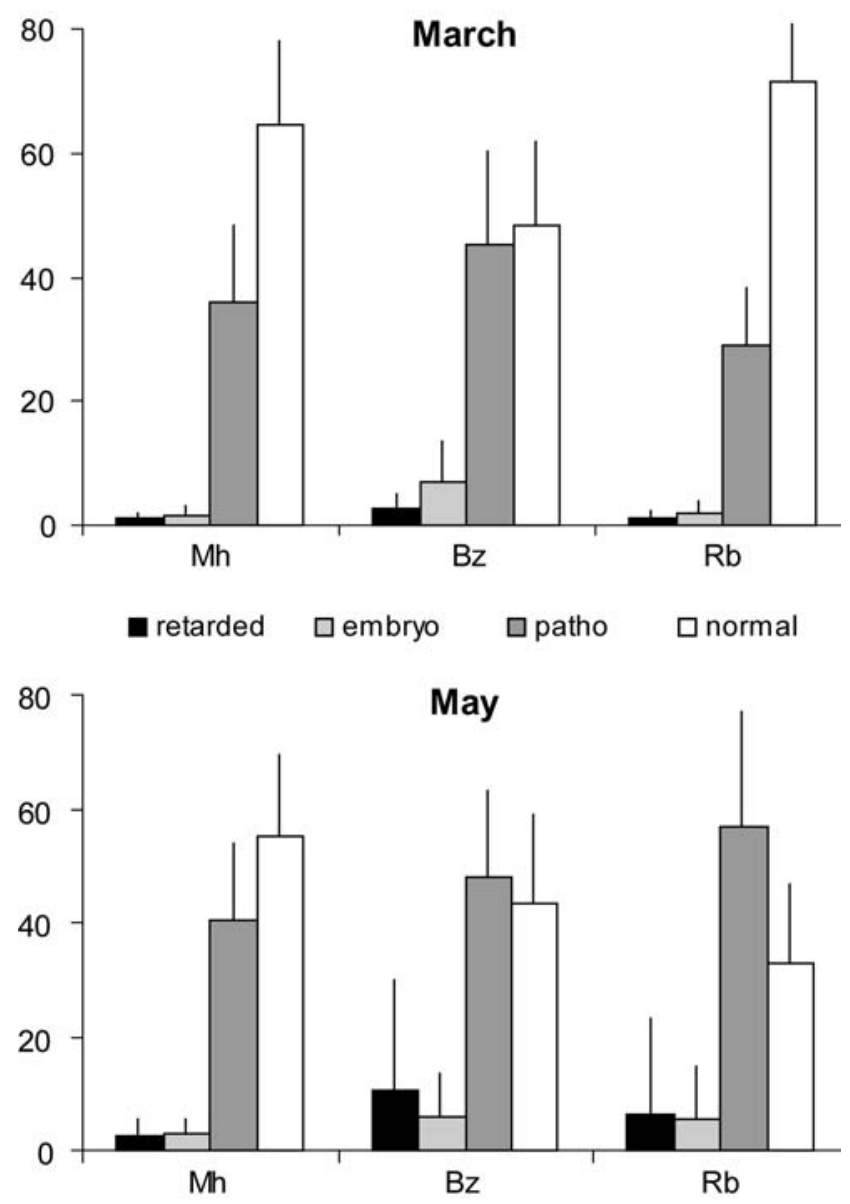

Figure 5. Graphic representation of the results of the Paracentrotus lividus embryonic development from the three studied populations in March and May 2001.

April (Mohammedia) $\left(P=2 \times 10^{-4}\right)$. At Rabat, four of the eight sampling dates showed righting times significantly higher than those for individuals from the other two populations (in May, June, September 1999; Tukey HSD test, $P<10^{-3}$ and in March $2000 P<10^{-3}$ ). In February 2000 , the righting times were significantly higher in Rabat than in Bouznika $\left(P<10^{-3}\right)$. There were no significant differences in righting times between the individuals of Bouznika and those of Mohammedia on five sampling dates (May, June, July, September 1999 and March 2000, Tukey HSD test, $P>0.5)$.

\section{Embryo development}

The fertilization rates of urchins were high, between 94 and 99\%, except at Bouznika in March 1999 (68\%). The frequencies of normal plutei were low (Figure 5). A significant difference in the distribution of larval classes was observed between the sites in March and May ( $\mathrm{G}$ test; $P<0.01)$. The comparison of sites in pairs showed that Rabat was significantly different from Bouznika in March $(P<0.01)$, and Rabat from Bouznika and Mohammedia in May $(P<0.05)$. Figure 5 showed the highest rate of normal plutei in Rabat in both March and May. The difference between Rabat and Bouznika appeared imputable to the higher rates of pathological plutei at Bouznika $(\mathrm{P})$ 

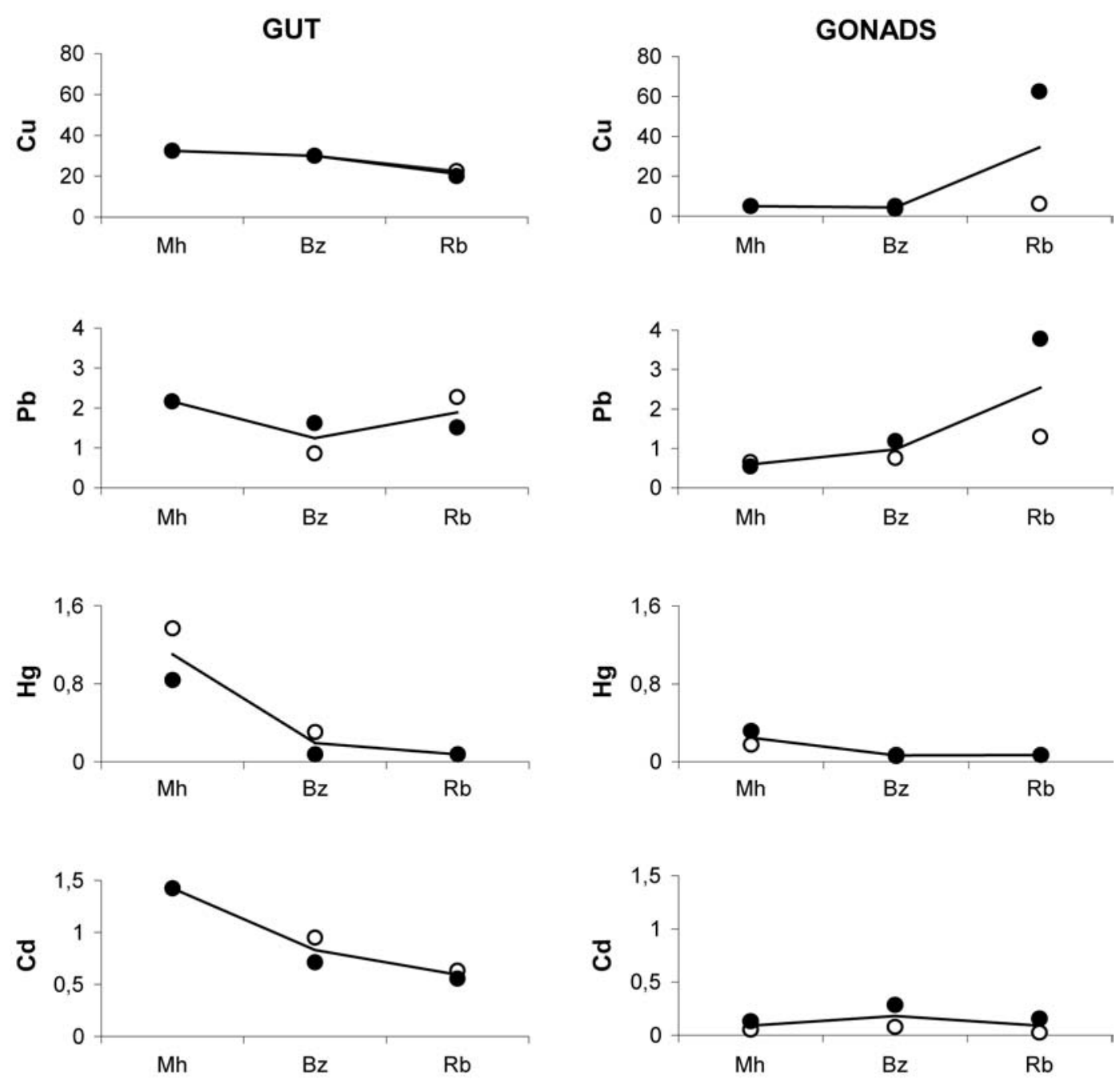

Figure 6. Mean concentrations of heavy metals $\left(\mathrm{mg} \mathrm{kg}^{-1} \mathrm{ww}\right)$ in the gut walls and gonads from the three Paracentrotus lividus populations. The sexes were analysed separately. Females, black dots; males, white dots. The line represents the mean values.

and the difference between Rabat and Mohammedia in May to the higher rates of retarded plutei $(\mathrm{R})$ at Mohammedia.

\section{Metal contamination}

For logistical reasons a pool of ten individuals of same sex were used for each site. If the results can be considered representative of the population, this method does not allow the values between sites and sex to be statistically compared. Low differences were observed between the sexes except for $\mathrm{Pb}$ and $\mathrm{Cu}$ in the sea urchin gonads from Rabat where these contaminants were higher in females (Figure 6). If we exclude these $\mathrm{Pb}$ and $\mathrm{Cu}$ values at Rabat, the metal concentrations were always higher in the gut wall than in the gonads and the $\mathrm{Cu}, \mathrm{Pb}, \mathrm{Hg}, \mathrm{Cd}$ values were on average respectively 6.8, 2.2, 3 and 10.7 times higher in the gut walls than in the gonads.

The highest levels of $\mathrm{Pb}$ and $\mathrm{Cu}$ occurred in the gonads of female sea urchins from Rabat. The highest concentrations in $\mathrm{Hg}$ and $\mathrm{Cd}$ were observed at Mohammedia: $\mathrm{Cd}$ in the gut walls, $\mathrm{Hg}$ in the gut walls and gonads of both sexes.

\section{DISGUSSION}

Characteristics of the Moroccan populations compared with various populations within the geographical range of the species

\section{Reproduction}

In the Atlantic Moroccan coasts Paracentrotus lividus has one annual gametogenic cycle with spawning occurring during a single season between March and May. This feature is characteristic of temperate echinoids, although $P$. lividus can spawn twice in a year in some regions, in particular in the Mediterranean Sea (Fenaux, 1968; Régis, 1980; Lozano et al., 1995; Guettaf et al., 2000). This difference could be due to different genetic adaptation between the Atlantic and Mediterranean populations (Duran et al., 2004). In the three studied sites in 2000 the spawning expressed by the GI decrease started in March probably a month earlier than in 1999 with respect to the GI values. The stage of gametogenesis expressed by a GI increase before spawning (Byrne, 1990) was obvious in the Bouznika and Rabat sites where it occurred between January and March, when seawater temperature increased again (from $14^{\circ} \mathrm{C}$ in January to about $17^{\circ} \mathrm{C}$ in February). Spawning can be triggered by seawater temperature or phytoplankton blooms (Starr et al., 1993). 
In the present study the gamete release did not seem to be triggered by the temperature increase as very low differences in seawater temperatures were observed between March $\left(17.1 \pm 0.3^{\circ} \mathrm{G}\right)$ and February $\left(16.8 \pm 1.1^{\circ} \mathrm{C}\right)$.

Gonad index values were low during the majority of the year, except before spawning, when they can reach values typical of well-nourished subtidal marine populations (Byrne, 1990; Guettaf et al., 2000; C. Fernandez, personal communication). The constraints of the intertidal environment (wave action, exondation, range of temperature) do not appear to limit gonad development during the prespawning period and, it is possible, that these sea urchin populations allocate more energy to reproduction under these physical conditions, as has been suggested by Lozano et al. (1995). Nutritional condition did not seem to be a limiting factor during this period because the RI was high before and after the spawning period; these values were superior to the RI of subtidal marine populations which are not nutrient limited (Régis, 1980; Nédélec et al., 1983; Lozano et al., 1995). The food is supplied by macrophytes the production of which starts from the end of winter when temperature and day length increase and by drifting algae (Boudouresque \& Verlaque, 2001). The RI decrease from May orJune can be explained by macrophyte disappearance due to sea urchin grazing and the high temperature level from June to October $\left(>22^{\circ} \mathrm{G}\right)$.

\section{Growth}

The relation between test diameter and age is very difficult to assess owing to the effects of environmental variability and also to variability due to intraspecific competition (Grosjean et al., 1996). In the three populations studied, the presence of a juvenile well-individualized cohort indicated a localized recruitment and a homogeneous growth rate for this modal class. The first cohort observed in the field in July with a diameter ranging from $7.2 \mathrm{~mm}$ at Bouznika to $12.4 \mathrm{~mm}$ at Mohammedia, probably represents the recruits of the previous year's spawning (Cellario \& Fenaux, 1990). Their growth rate during the first year of settlement in the three sites was slower than that observed in other populations (Azzolina, 1988; Grosjean et al., 1996; Fernandez, 1996). This conclusion is consistent with the small number of individuals with diameters above $30 \mathrm{~mm}$. In addition, an initial study analysing the growth zones in these populations (L.A. Chentoufi, personal communication) has shown the presence of between two to six growth rings within the relatively narrow range of test diameters observed (15 to $35 \mathrm{~mm}$ in Rabat and Bouznika, and 15 to $45 \mathrm{~mm}$ in Mohammedia) and a large variability in the relationships between the test diameter and the number of rings. It is not known if the growth rings represent annual intervals in the three populations. Food availability is one of the most influential environmental factors controlling sea urchin growth (Lawrence \& Lane, 1982). The low food consumption between June and November supported this hypothesis but other factors can be involved in the present situation such as wave action, intraspecific competition, aerial and seawater temperature or pollution.

\section{Righting time}

This parameter measures the degree of the coordinating capacities between the tube foot and spine and reflects the general physiological state of the animal. It was first used on P. lividus by Axiak \& Saliba (1981) to test sublethal effects of oil pollution on this species. The present study monitored for the first time the annual variations of this parameter. A decrease was observed between July and September and an increase between February and March (Bouznika and Rabat) or April (Mohammedia). These changes could be related to the sexual status of the animals which had a period of high gonadal development between January and March followed by a decrease in the GI until June. The lowest values, observed in September and February, were near published reference values (Axiak \& Saliba, 1981), that is about 100 s. The maximum values observed in Rabat in May and June 1999 (<250s) can be the sign of a population temporally stressed.

\section{Embryo development}

According to the criteria established by Kobayashi (1991), the fertilization rate $(>90 \%)$ observed at the three Moroccan sites shows that fertilization was not inhibited by the environmental conditions in the present populations, except in March at Bouznika. Embryo development was affected, however. The low number of normal plutei estimated for the sites in March $(<70 \%)$ and more pronounced in May (probably due to the nearly over spawning period) indicated a severe inhibition of the larval development according to the Kobayashi criteria (Kobayashi, 1991). This inhibition was obvious at Bouznika where the rate of normal plutei was 48 and $33 \%$ in March and May, respectively. Usually, the toxicity of sediment-associated contaminants has been assessed with bioassays using embryonic and larval development of P. lividus, however, few studies have been carried out on the embryo development of natural populations subjected to anthropogenic disturbances. A study on the populations of Sphaerechinus granularis in the Bay of Brest (France) described frequencies of normal plutei ranging from 59\% to $78 \%$ in a site polluted by heavy metals $(\mathrm{Cd}, \mathrm{Hg}, \mathrm{Zn}$ and $\mathrm{Fe}$ ), while reference sites had values above $90 \%$ (Guillou et al., 2000). Strongylocentrotus intermedius in the Bay of Amursky (Sea of Japan), a site highly polluted by metals $(\mathrm{Zn}, \mathrm{Pb}, \mathrm{Cd}, \mathrm{Cr}$ and $\mathrm{Cu})$ developed between 0 and $68 \%$ normal plutei depending on location within the bay, as compared with $90 \%$ normal plutei in the nearby Bay of Vityaz that was used as a reference site (Naidenko, 1997).

\section{Metal contamination}

Cd concentrations in both gonads and gut walls were lower than the mean value reported in the gonads and gut walls from sea urchins in the literature (see review by Guillou et al., 2000). Pb concentrations were well below the maximum data observed in Marseille (Augier et al., 1989) except for the gonads of individuals from Rabat. However, $\mathrm{Hg}$ concentrations were much higher in the gut walls of sea urchins from Mohammedia than the maximum published values available for sea urchins (Sphaerechinus granularis: Bay of Brest). And, in all three stations, $\mathrm{Cu}$ concentrations were close to or higher (Rabat) than the maximum literature values that were observed in the Mediterranean Sea from Marseille, Naples or Calvi (Augier et al., 1989; Warnau et al., 1995). The high $\mathrm{Pb}$ and $\mathrm{Hg}$ levels in specimens from Rabat and 
Mohammedia, respectively, are consistent with the specific industrial activities in those sites: pottery making in Rabat and the petrochemical industry in Mohammedia. The observed metal bioaccumulation in the populations indicates an incomplete or not immediate dispersion of contaminants by the high current and wave action of this coastal zone. These contaminants, mainly $\mathrm{Hg}$ and $\mathrm{Cd}$, would be bioaccumulated in sea urchin by macrophytes consumption as attested by the higher metal concentration in the sea urchin gut walls.

From the observed levels in these populations, this metal pollution would have more of an effect on the sea urchin larval development than on their somatic growth, which is essentially controlled by the food quality and quantity (Guillou et al., 1997).

\section{Variations at the Moroccan scale}

The present study highlights the distinctive development of the populations of Bouznika compared with the two other Moroccan populations. All the criteria used here, except the righting time, separate this population from the other two. At this site, the first year-class had the lowest growth rate and the adults had the lowest gonad and repletion indices. With regards to larval development, the lowest percentage of normal plutei was recorded from Bouznika concomitant with a high rate of pathological plutei, the highest rate in both months of the study.

Even if contamination by heavy metals, and especially by $\mathrm{Cu}$, can explain in part the poor development of larvae (Heslinga, 1976; Kobayashi, 1994), they cannot explain the differences observed between the three Moroccan stations. Bouznika had lower values of $\mathrm{Pb}$ in the gonads and gut walls and lower values of $\mathrm{Cu}$ in the gonads as compared with Rabat. Relative to Mohammedia, Bouznika had lower values of $\mathrm{Hg}$ in the gut walls and gonads and lower values of $\mathrm{Cd}$ in the gut walls. Overall, Bouznika is the least polluted site with respect to the metals analysed. Other environmental factors have to be considered. The main difference between the sampling site of Bouznika and the other sites is the presence of a temporary river that flows into the sea along the ledge inhabited by the sea urchin population. The salinity measured at the time of sampling was 24 and the wadi can cause, during winter low tide, more important decreases (up to 14, A. Bayed, personal observation). Even if the flooding was episodic, the gonad quality can be affected. Paracentrotus lividus is a stenohaline species; moreover Dinnel et al. (1987) and His et al. (1999) showed that metal toxicity increases in this species when salinity decreases from 30 to 25 .

\section{CONCLUSIONS}

In view of the results presented, it appears that the intertidal populations of Paracentrotus lividus from the northern part of the Moroccan Atlantic coast have:

(1) a low juvenile growth rate;

(2) a clear annual gametogenic cycle with a high GI increase between January and March concomitant with a temperature increase followed by a single spawning period occurring between March and May/
June. The investment in reproduction would be favoured by energy allocation to the gonad at the expense of somatic growth and by the increase in consumption during the beginning of the period of macrophyte production;

(3) a severe inhibition of larval development partly attributed to high $\mathrm{Cu}$ contamination at all three sites;

(4) contamination by $\mathrm{Pb}$ or $\mathrm{Hg}$ that related to specific local industries and insufficient dispersion of these pollutants.

Comparisons between the three populations studied highlighted the distinctive development of the population at Bouznika. The degraded health condition of this population could be due to the presence of a seasonal river near the site which temporarily reduces the salinity, affecting directly the sea urchin physiology and increasing metal toxicity indirectly.

This study was supported in part by the Moroccan network REMER for Marine Sciences and Techniques. The authors thank the students L.A. Chentoufi, R. Leugenizi and S. Moujtahid for their contribution in the field and laboratory, Drs S. Benbrahim, A. Chafik and H. Bazairi from the INRH and University of Casablanca for their help and good advice, Dr Jennifer Guarini for constructive comments in the writing of the English manuscript and Monique Briand for help in iconography.

\section{REFERENCES}

Augier, H., Ramonda, G., Rolland, J. \& Santimone, M., 1989. Teneurs en métaux lourds des oursins comestibles Paracentrotus lividus (Lamarck) prélevés dans quatre secteurs tests du littoral de Marseille (Méditerranée, France). Vie Marine, HS10, 226239.

Axiak, V. \& Saliba, L.J., 1981. Effects of surface and sunken crude oil on the behaviour of a sea urchin. Marine Pollution Bulletin, 12, $14-19$.

Azzolina, J.F., 1988. Contribution à l'étude de la dynamique de populations de l'oursin comestible Paracentrotus lividus (Lmck). Croissance, recrutement, mortalité, migrations. Thèse de Doctorat de l'Université d'Aix-Marseille II, France.

Bayed, A., 1991. Etude écologique des écosystèmes de plages de sable fin de la côte atlantique marocaine. Thèse de Doctorat est Sciences Biologiques, Université Mohammed V, Rabat, Maroc.

Boudouresque, C.F. \& Verlaque, M., 2001. Ecology of Paracentrotus lividus. In Edible sea urchins; biology and ecology (ed. J.M. Lawrence), pp. 177-216. Amsterdam: Elsevier Sciences B.V.

Byrne, M., 1990. Annual reproductive cycles of the commercial sea urchin Paracentrotus lividus from an exposed intertidal and a sheltered subtidal habitat on the west coast of Ireland. Marine Biology, 104, 275-289.

Cellario, C. \& Fenaux, L., 1990. Paracentrotus lividus (Lamarck) in culture (Larval and Benthic phases): parameters of growth observed during two years following metamorphosis. Aquaculture, 84, 173-188.

Chafik, A., Cheggour, M., Cossa, D., Benbrahim, S. \& Sifeddine, M., 2001. Quality of Moroccan Atlantic coastal waters: water monitoring and mussel watching. Aquatic Living Resource, 14, 239-249.

Cheggour, M., 1989. Bioaccumulation de quelques éléments métalliques ( $\mathrm{Cu}, \mathrm{Zn}, \mathrm{Pb}, \mathrm{Ni}, \mathrm{Cr}, \mathrm{Mn}, \mathrm{Fe}, \mathrm{V})$ chez un mollusque bivalve, Scorbicularia plana, dans l'estuaire du Bou Regreg (côte atlantique marocaine). Bulletin de l'Institut Scientifique de Rabat, 13, 129-133. 
Dinnel, P., Link, J. \& Stober, Q., 1987. Improved methodology for sea urchin sperm cell bioassay for marine waters. Archives of Environmental Contamination and Toxicology, 16, 23-32.

Dinnel, P.A., Pagano, G.G. \& Oshida, P.S., 1988. A sea urchin test system for marine environmental monitoring. In Echinoderm biology (ed. R.D. Burke et al.), pp. 611-619. Rotterdam: A.A. Balkema.

Donais, M.K. et al., 1997. Certification of three mussel tissue standard reference materials (SRM) for methylmercury and total mercury content. Fresenius' fournal of Analytical Chemistry, 358, 424-430.

Duran, S., Palacin C., Becerro, A.M., Turon, X. \& Gonzalo, G., 2004. Genetic diversity and population structure of the commercially harvested sea urchin Paracentrotus lividus (Echinodermata: Echinoidea). Molecular Ecology, 13, 3317-3328.

Fenaux, L., 1968. Maturation des gonades et cycle saisonnier des larves chez A. Lixula, P. lividus et P. microtuberculatus (Echinides) à Villefranche sur Mer. Vie et Milieu, 19, 1-52.

Fernandez, C., 1996. Croissance et nutrition de Paracentrotus lividus dans le cadre d'un projet aquacole avec alimentation artificielle. Thèse de Doctorat d'Océanologie, Université de Corse, France.

Grosjean, P., Spirlet, C. \& Jangoux, M., 1996. Experimental study of growth in the echinoid Paracentrotus lividus (Lamarck, 1816) (Echinodermata). Journal of Experimental Marine Biology and Ecology, 201, 173-184.

Guettaf, M., San Martin, G.A. \& Francour, P., 2000. Interpopulation variability of the reproductive cycle of Paracentrotus lividus (Echinodermata: Echinoidea) in the southwestern Mediterranean. Fournal of the Marine Biological Association of the United Kingdom, 80, 899-907.

Guillou, M., Judas, A. \& Quiniou, F., 1997. Variabilité de divers paramètres du développement post métamorphique de l'oursin S. granularis liée à la qualité l'environnement. Annales de l'Institut Océanographique, Paris, 73, 49-57.

Guillou, M., Quiniou, F., Huart, B. \& Pagano, G., 2000. Comparison of embryonic development and metal contamination in several populations of the sea urchin Sphaerechinus granularis (Lamarck) exposed to anthropogenic pollution. Archives of Environmental Contamination and Toxicology, 39, 337344.

Heslinga, G.A., 1976. Effects of copper on the coral reef echinoid Echinometra mathaei (de Blainville). Marine Biology, 35, 155-160.

His, E., Heyvang, I., Geffard, O. \& De Montaudouin, X., 1999. A comparison between oyster (Crassostrea gigas) and sea urchin (Paracentrotus lividus) larval bioassays for toxicological studies. Water Research, 33, 1706-1718.

Kobayashi, N., 1991. Marine pollution bioassay by using sea urchin eggs in the Tanabe Bay, Wakayama Prefecture, Japan, 1970-1987. Marine Pollution Bulletin, 23, 709-713.
Kobayashi, N., 1994. Application of eggs of the sea urchin Diadema setosum in marine pollution bioassays. Phuket Marine Biological Center Research Bulletin, 59, 91-94.

Lawrence, J.M. \& Cowell, B.C., 1996. The righting response as an indication of stress in Stichaster striatus (Echinodermata, Asteroidea). Marine and Freshwater Behaviour and Physiology, 27, 239-248.

Lawrence, J.M. \& Lane, P., 1982. The utilisation of nutrients by postmetamorphic echinoderms. In Echinoderm nutrition (ed. M. Jangoux et al.), pp. 331-372. Rotterdam: A.A. Balkema.

Lozano, J., Galera, J., Lopez, S., Turon, X., Palacin, C. \& Morera, G., 1995. Biological cycles and recruitment of Paracentrotus lividus (Echinodermata: Echinoidea) in two contrasting habitats. Marine Ecology Progress Series, 122, 179-191.

Macdonald, P.D.M. \& Pitcher, T.J., 1979. Age-groups from sizefrequency data: a versatile and efficient method of analysing distribution mixtures. Fournal of the Fisheries Research Board of Canada, 36, 987-1001.

Naidenko, T., 1997. Abnormality of development in Strongylocentotus intermedius (A. Agassiz) larvae from polluted habitat in Amursky Bay, Peter the Great Bay. Publications of the Seto Marine Biological Laboratory, 38, 1-11.

Nédélec, H., Verlaque, M. \& Dallot, S., 1983. Note préliminaire sur les fluctuations de l'activité trophique de Paracentrotus lividus dans l'herbier de Posidonies. Rapports de la Commission Internationale pour l'Exploration de la Mer Méditerranée, 28, 153-155.

Pagano, G., Corsale, G., Dinnel, P.A., Esposito, A. \& Romaña, L.A., 1989. Use of sea urchin sperm and embryo bioassay in testing the sublethal toxicity of realistic polluants levels. Advances in Applied Biotechnology, 5, 153-164.

Pagano, G. et al., 1996. Cytogenetic, developmental, and biochemical effects of aluminium, iron, and their mixture in sea urchins and mussels. Archives of Environmental Contamination and Toxicology, 31, 466-474.

Régis, M.B., 1980. Etude des possibilités d'élevage des oursins réguliers en fonction de la valeur de certains indices physiologiques. Oceanologica Acta, 3, 7-15.

Starr, M., Himmelman, J.H. \& Therriault, J.C., 1993. Environmental control of green sea urchin, Strongylocentrotus droebachiensis, spawning in the St. Lawrence Estuary. Canadian Fournal of Fisheries and Aquatic Sciences, 50, 894-901.

Warnau, M., Ledent, G., Temara, A., Bouquegneau, J.M., Jangoux, M. \& Dubois, P.H., 1995. Heavy metals in Posidonia oceanica and Paracentrotus lividus from seagrass beds of northwestern Mediterranean. Science of the Total Environment, 171, 9599.

Submitted 4 November 2004. Accepted 8 April 2005. 